\title{
Wild Rosa L. taxa of the National Nature Park 'Podilskyi Tovtry' (Podolian Hills, Western Ukraine)
}

\author{
Anna Sołtys-Lelek ${ }^{*} \&$ Halyna Oliiar ${ }^{2}$
}

\author{
${ }^{1}$ Ojców National Park, 32-045 Sułoszowa, Ojców 9, Poland \\ ${ }^{2}$ Medobory Nature Reserve, Mitskevycha 21, 48210, smt. Hrymailiv, Husiatynskyi raion, Ternopilska Oblast, Ukraine \\ * corresponding author (e-mail: ana_soltys@wp.eu)
}

\begin{abstract}
The present paper discusses the wild roses of the National Nature Park 'Podilskyi Tovtry'. The purpose of the work was to compile a full list of the wild Rosa taxa growing in the study area and present their distribution. Based on the field studies during the years 2009-2013 and published data, 20 taxa have been recorded, among them: 16 native species (including three hybrids with the rank of species), 2 anthropophytes and 2 hybrids. However, the taxonomical status of Rosa caryophyllacea Besser is not clear and species requires taxonomical revision. Three new rosa species for the Park were found during the studies. These are: Rosa micrantha, $R . \times_{\text {subcanina }}$ and $R . \times_{\text {subcollina }}$. The list of the roses occurring in this area is still far away from being completed, therefore, further research is needed.
\end{abstract}

Key words: Rosa, Rosaceae, checklist of the roses, National Nature Park 'Podilskyi Tovtry', Ukraine

\section{Introduction}

The occurrence of polymorphism was the reason for the presence of many classification systems within the genus Rosa L. Recently, considering the classification based on morphological features and additional cytology and karyological studies, 31 wild growing rose species have been found in the European territory, excluding former USSR countries (Popek 2007). Henker (2000) lists 28 rose species and Zieliński (1985) 17 in the Caninae section. The distribution of the genus Rosa L. in the East Europe requires thorough revision based upon the current taxonomic nomenclature. For example, 85 wild Rosa species are given in the Vascular Plants of Ukraine (Mosyakin \& Fedoronchuk 1999) and 29 species in the Atlas of Florae Europeae (Kurtto et al. 2004). Also, the ranges of many rose species have not been sufficiently recognized yet.

No thorough searches of Rosa species have been conducted in the National Nature Park 'Podilskyi Tovtry' (NNPPT) yet. The studies carried out in the Park area so far concentrated on the occurrence of relic, endemic, rare and protected species. Their main aim was the search for plants with special significance for xerother- mic flora (Moroz 1970; Levanets et al. 2004; Lyubinska 2013). The monographies concerning vascular flora of NNPPT provide only the general data presenting mainly the names of species, but not their distribution in the Park (Lyubinska et al. 1999; Novosad et al. 2009).

The highest number of rose species was reported by Lyubinska et al. (1999) and Novosad et al. (2009). These scientists classified 37 rose species in total, among them, 21 species functioning synonymously in the current taxonomic nomenclature (among others, Kurtto et al. 2004; Popek 1996, 2007; Zieliński 1985, 1987; http://www.eu-nomen.eu; http://www. theplantlist.org); e.g.: Rosa andegavensis Bast. $(=R$. canina L.), R. andrzejowskii Staven ex Besser (=R. sherardii Dav.), R. balsamica Besser (=R. canina), R. biserrata Mérat. $(=R$. canina $), R$. $\times$ boreykiana Besser $(=R$. canina s.1.), R. canina L., $R$. carophyllacea Besser, $R$. ciesielskii Błocki ( $=$ R. canina), R. corymbifera Borkh. $(=R$. canina $), R$. crenatula Chrshan. (=R. gallica $\mathrm{L}$.), $R$. czackiana Besser (=R. gallica), R. dumalis Bechst., $R$. frutetorum Besser (=R. canina), $R$. gorenkensis Besser, R. inodora Fr., R. jundzillii Besser, R. lazarenkoi Chrshan. (=R. dumalis), R. litvinovii Chrshan. $(=R$. canina), R. livicensis Besser (=R.jundzillii), R. nitidula 
Besser (=R. canina), R. parviuscula Chrshan. \& Laseb $(=R$. gallica), $R$. pimpinellifolia $(=R$. spinosissima $\mathrm{L}$.), $R$. podolica Tratt. (=R. dumalis), $R$. porrectidens Chrshan. Et Laseb., R. rubiginosa L., R. rubrifolia Vill. (=R. glauca Vill.), R. schmalhauseniana Chrshan. ( $=R$. canina), R. scherardii Dav., R. spinosissima L., R. subafzeliana Chrshan. (=R. dumalis), R. subglabra Borbás $(=R$. canina s.1.), R. tomentosa Sm., $R$. unicella Besser $(=R$. canina), $R$. villosa L., $R$. volhynensis Chrshan. (=R. rubiginosa) and anthropophytes $R$. glauca Vill. and $R$. rugosa Thunb.

Rosa $\times$ subcanina (H. Christ) R. Keller - a new species for the flora of the NNPPT was found during the studies in 2009 (Soltys-Lelek 2013). Rosa $\times$ subcanina, regarded as a taxon of hybrid origin (R. dumalis Bechst. $\times R$. canina L.), is currently classified by some researchers as a separate species (Henker 2000).

The so far mentioned rose species coming from the Podolia area were found either in single localities or reported as occurring 'everywhere' or 'frequently'. Also, some of the mentioned species have synonymous names, e.g., $R$. canina has 12 different names.

Therefore, the search focused on the preparation of a very detailed list of rose species based on the current taxonomic nomenclature (Zieliński 1987; Popek 1996) and species localities in the NNPPT.

\section{Study area}

The NNPPT, 2,613.16 $\mathrm{km}^{2}$ in area, was established in 1996 and signed under the Decree No. 476-96 by the President of Ukraine on the 27th of June 1996. NNPPT has been registered in the Podilskyi Region of National Ecological Network of Ukraine since 2000 (according to the Law of Ukraine of 21.09.2000, No. 1989-III). The park is situated in the Khmelnytskyi Oblast (province) in southern part of western Ukraine (Fig. 1). NNPPT is the biggest protected area in Ukraine.

Tovtry is situated on a low mountainous ridge with the maximum height of $350-400 \mathrm{~m}$ a.s.l. within the Park limits and an average height of 60-65 $\mathrm{m}$ a.s.1. for the surrounding plateau. Its geological structure is formed from the Miocene barrier coral reef consisting of different types of limestone, elevated due to tectonic movements (Fig. 2). A large number of similar rock structures occurs only in the United Kingdom and USA (http://www.tovtry.com/en/info/geo/index.html).

The diversified land forms, formed as a result of karst processes, caused the differentiation of biological sites in the park, which consequently influenced its vegetation. 2977 plant species requiring different ecological conditions (60 of them listed in the Ukrainian Red Book) occur in the NNPPT area (http://www.tovtry.com).

Agricultural area covers ca $75 \%$ of the Park, forests and non-forest vegetation - nearly $15 \%$; non-forest wetlands - only $4 \%$. The vegetation cover is formed by oak, mixed hornbeam-oak-ash and beach forests and patches of xerothermic grasslands and meadows (Lyubinska 2013).

\section{Material and methods}

Plant material was collected in 2009-2013. It included fragments of short and long shoots of roses. The localities of common and easy to identify in the field taxa, such as Rosa canina L., were only sporadically recorded. All herbarium materials are deposited in the Herbarium of the Ojców National Park (Ojców, Poland).

Data were collected from 44 localities. The names of places were based on www.google.pl/maps (Fig. 1, Appendix 1). The locality names (encoded as numbers) in the presented species list were supplemented with the author's name abbreviation and the year when the field observations were made or specimens collected. Data from literature were also included.

Taxonomic approach and nomenclature were based on the works of Popek (1996, 2007), Zieliński (1985, 1987), Henker (2000), Kurtto et al. (2004) and on the websites: http://www.ville-ge, http://ww2.bgbm.org/ EuroPlusMed and http://www.gbif.org/species.

The geographical elements for each species follow Popek (2007) and Zając \& Zając (2009). For anthropophytes their native ranges are given.

Abbreviations and symbols used in the list of species: HO - Halyna Oliiar, SL - Anna Sołtys-Lelek; * - anthropophyte, leg. - legit, obs. - observation; geographical elements, A - Asian element, CE - European-temperate sub-element, $\mathrm{CE}$ : a-ce-Alpine-CentralEuropean distributional type, CE: a-ne-Alpine-northern-European distributional type, $\mathrm{M}$ - Mediterranean element, ES - Euro-Siberian sub-element, IR - IranoTuranian element; $\mathrm{e}$ - eastern, $\mathrm{n}$ - northern, $\mathrm{s}$ - southern, $\mathrm{w}$ - western; sa - extension in the beginning of diagnosis to the Atlantic region of Europe.

\section{Results}

The list contains 20 taxa of the genus Rosa L., belonging to the sections: Pimpinellifoliae DC. (1 species), Cinnamomeae D.C. (2 species), Caninae DC. em. H. Christ (15 taxa) and Rosa (1 species). Among them, there are 16 native species (including 2 native hybrid forms at the rank of species), 2 anthropophytes and 2 hybrid forms.

\section{Sect. Pimpinellifoliae DC}

Rosa spinosissima L. (=R. pimpinellifolia L.) ES. The species occurs in the Park area (Lyubinska et 


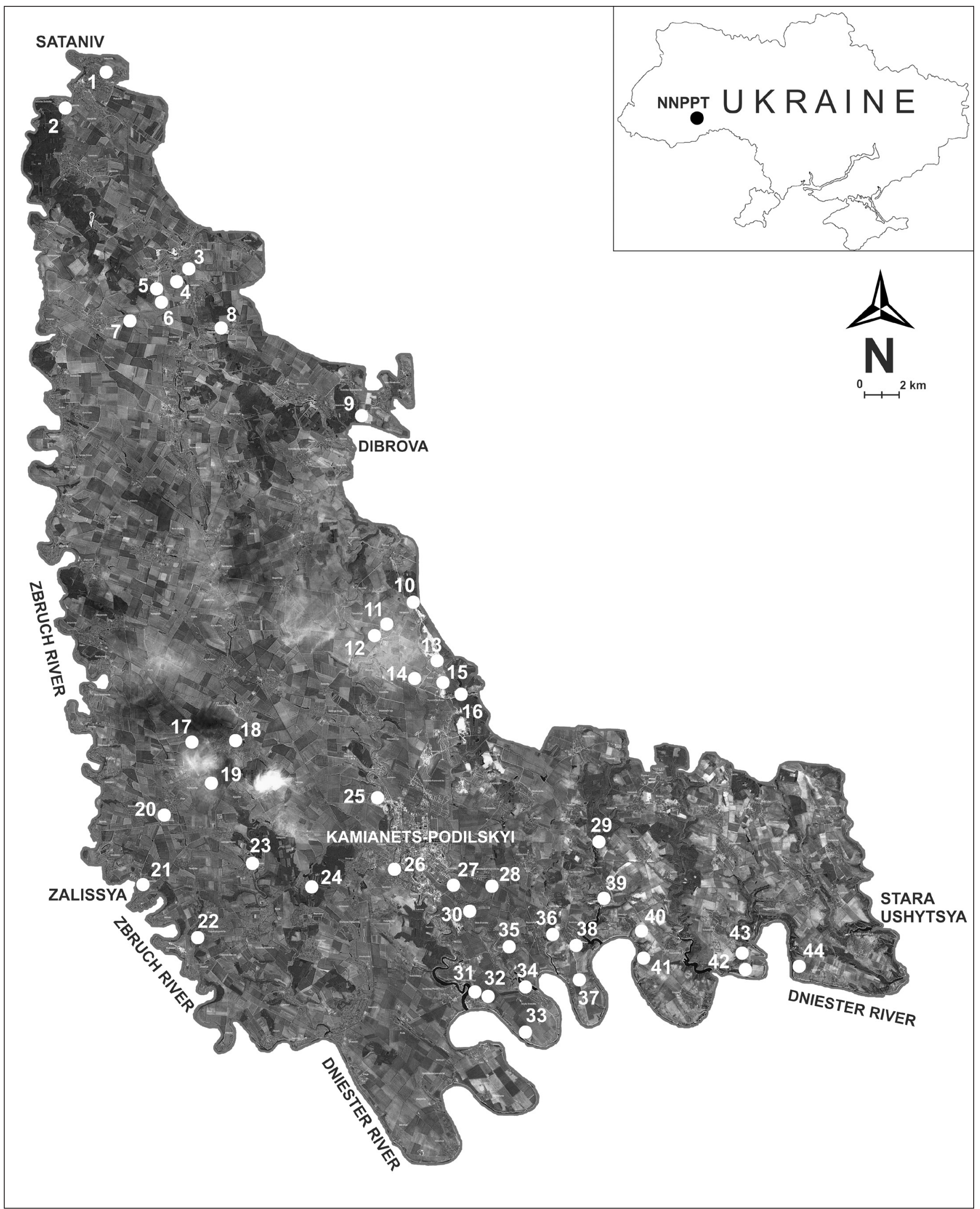

Fig. 1. Distribution of localities in the study area Explanation: list of localities cf. Appendix 1 


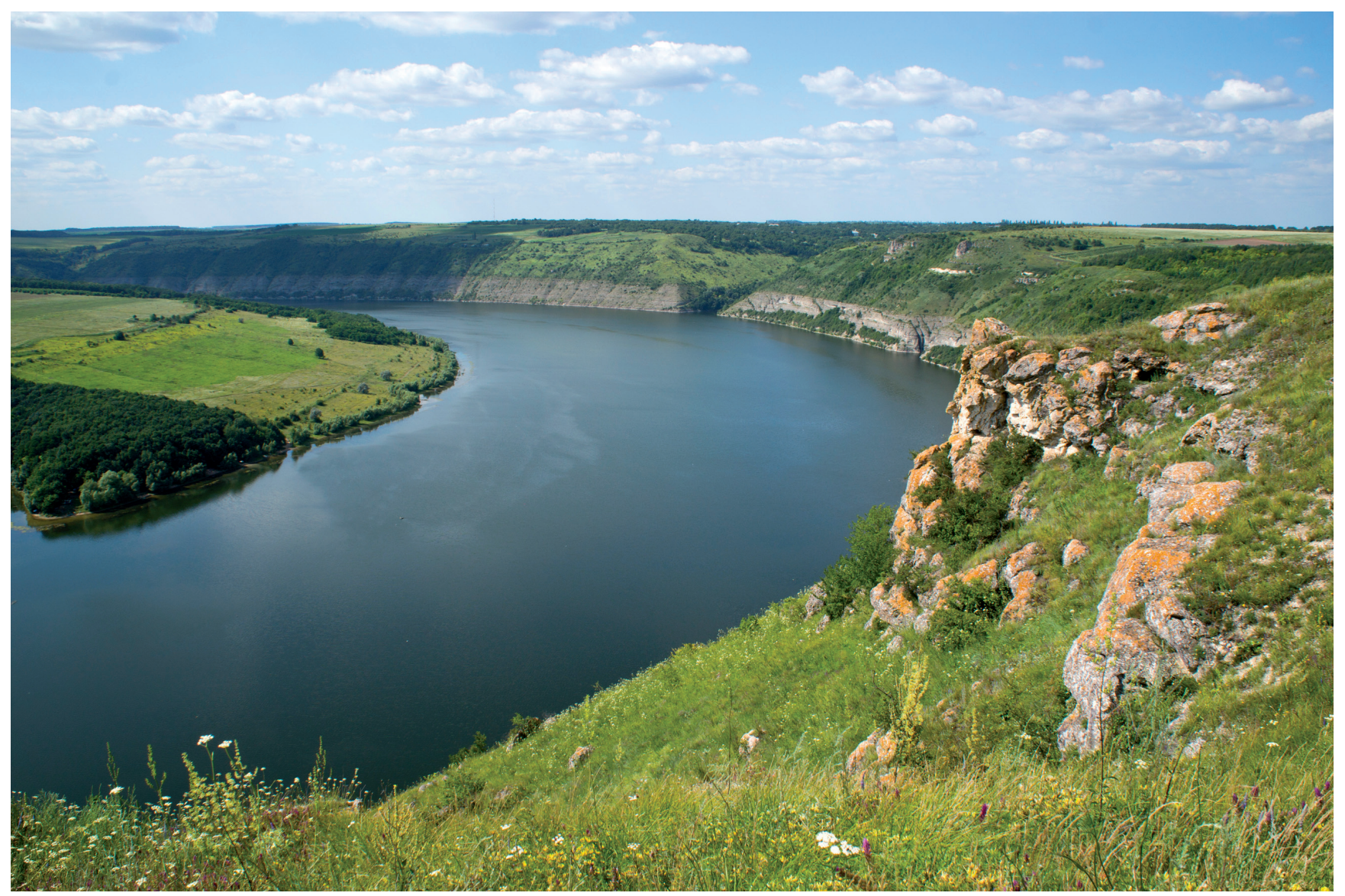

Fig. 2. National Nature Park 'Podilskyi Tovtry’ near Subich village (photograph by A. Sołtys-Lelek, 2013)

al. 1999; Novosad et al. 2009) and in the 'Podilskyi Tovtry' range (Moroz 1970). 1 locality stated by the authors: 30 (leg. SL, 2010).

\section{Sect. Cinnamomeae DC}

Rosa gorenkensis Besser - ES. Generally reported from the Park area (Novosad et al. 2009). Not found during this research.

* Rosa rugosa Thunb. - A(e). Generally reported from in the Park area (Lyubinska et al. 1999). Not found during this study.

\section{Sect. Caninae DC. emend. H. Christ}

*Rosa glauca Pourr. (=Rosa rubrifolia Vill.) CE: a-ce. Generally reported from the Park area (Lyubinska et al. 1999; Novosad et al. 2009). Not found during this study.

$R$. dumalis Bechst. (=R. glauca Vill, $R$. caesia Sm., $R$. coriifolia Fr., $R$. lazarenkoi Chrshan., $R$. podolica Tratt., R. subafzeliana Chrshan.) - CE-M(n). The species reported as $R$. lazarenkoi Chrshan. Generally reported from the Park area (Lyubinska et al. 1999; Novosad et al. 2009). Found in four varieties:
- R.d. var. afzeliana (Fr.) Boulenger (=R. subafzeliana Chrshan.). The variety reported as $R$. subafzeliana Chrshan. Generally reported from the Park area (Novosad et al. 2009). 4 localities stated by the authors: 12, 20, 22, 33 (leg. SL, 2013).

- R. $d$. var. dumalis -9 localities stated by the authors: 25 (leg. SL, 2010); 4, 5, 8, 10, 11, 15, 18, 31 (leg. SL, 2013).

- R.d. var. coriifolia (Fr.) Boulenger-6 localities stated by the authors: 27, 30 (leg. SL, 2010); 8, 9, 37, 41 (leg. SL, 2013).

- R.d. var. caesia (Sm.) Boulenger-The variety generally reported as $R$. lazarenkoi Chrshan from the Park area (Lyubinska et al. 1999).

Rosa villosa L. - CE-M. Generally reported from the Park area and frequent in the central area of the 'Podilskyi Tovtry' range (Moroz 1970). Not found during the research.

Rosa sherardii Dav. var. sherardii $(=R$. andrzejowskii Steven ex Besser.)-CE: a-ne. Generally reported from the Park area (Lyubinska et al. 1999; Novosad et al. 2009). 3 localities stated by the authors: 5, 6, 8 (leg. SL, 2013).

Rosa tomentosa $\mathrm{Sm}$. var. tomentosa - sa-CE$\mathrm{M}(\mathrm{n})$. Generally reported from the Park area (Lyubinska 
et al. 1999; Novosad et al. 2009). 4 localities stated by the authors: 16 (leg. SL, 2010); 6, 13, 15 (leg. SL, 2013).

Rosa rubiginosa L. (=Rosa eglanteria L.) - saCE-M(n). Generally reported from the Park area (Lyubinska et al. 1999, Novosad et al. 2009) and from 4 localities: 26 (Levanets et al. 2004), 39 (Khrzhanovsky 1954), 38 (Moroz 1970), Sataniv (Khrzhanovsky 1954). The species found in three varieties:

- R. r. var. rubiginosa - 7 localities stated by the authors: 16, 29, 30 (leg. SL, 2010); 33, 39, 40, 44 (leg. SL, 2013).

- R. r. var. umbellata (Leers) Dumort. - 18 localities stated by the authors: $3,4,5,9,11,13,14,15$, 22, 23, 31, 34, 35, 36, 37, 39, 41, 43 (leg. SL, 2013).

- R. r. var. jenensis (M. Schulze) H. Christ. -2 localities stated by the authors: 5, 42 (leg. SL, 2013).

Rosa micrantha Borrer ex Sm. var. micranthasa-CE(s)-M. Anew Rosa species for the flora of NNPPT, not previously reported from the study area. 1 locality stated by the authors: 32 (leg. SL, 2013).

Rosa inodora Fr. var. popekii (Klášt.) Popek $\mathrm{CE}(\mathrm{w})$. Generally reported from the Park area (Novosad et al. 2009). 1 locality stated by the authors: 30 (leg. SL, 2010).

Rosa canina L. (=R. andegavensis Bast., $R$. balsamica Besser, $R$. biserrata Mérat., $R$. $\times$ boreykiana Besser, R. ciesielskii Błocki, R. corymbifera Borkh., $R$. frutetorum Besser, $R$. klukii Besser, $R$. litvinovii Chrshan., R. nitidula Besser, R. schmalhauseniana Chrshan., R. subglabra Borbás, R. unicella Besser.) sa-CE-M-IR. The species generally reported from the Park area (Lyubinska et al. 1999, Novosad et al. 2009) and as frequent in the southern part of Podole region (Moroz 1970): 26 (Khrzhanovsky 1954; Levanets et al. 2004), Sataniv (Khrzhanovsky 1954; Moroz 1970). Found in seven varieties.

- R. c. var. canina -9 localities stated by the authors: 2 (leg. SL, 2009); 30, 44 (leg. SL, 2010); 4, 17, 18, 20, 23, 33 (leg. SL, 2013).

- R. c. var. andegavensis (Bastard) Desp. (=R. andegavensis Bast., $R$. litvinovii Chrshan.) - 32 localities stated by the authors: 16, 26, 27, 44 (leg. SL, 2010); $4,6,8,9,10,11,12,13,14,15,17,20,21,22,23,28$, $31,32,33,34,35,36,37,39,40,41,42$, 43 (leg. SL, 2013).

- R. c. var. dumalis -28 localities stated by the authors: 26, 29, 44 (leg. SL, 2010); 3, 4, 5, 6, 8, 10, 13, $14,15,17,19,20,22,23,28,31,32,33,35,36,37,39$, 40, 41, 42 (leg. SL, 2013).

- R.c. var. blondeana (Ripart) Crépin-2 localities stated by the authors: 30 (leg. SL, 2010); 42 (leg. SL, 2013).

- R. c. var. deseglisei (Boreau) Crépin $(=R$. schmalhauseniana Chrshan.) -6 localities stated by the authors: 2 (leg. SL, 2009); 26 (leg. SL, 2010); 5, 10, 11, 34 (leg. SL, 2013).

- R. c. var. corymbifera (Borkh.) Boulenger $(=R$. corymbifera Borkh $)-38$ localities stated by the authors: 2 (leg. SL, 2009); 16, 26, 27, 29, 30, 44 (leg. SL, 2010); 3, 6, 7, 8, 9, 10, 11, 12, 13, 14, 15, 17, 18, $19,20,21,22,23,28,31,32,33,34,35,36,37,39,40$, 41, 42, 43 (leg. SL, 2013).

- R.c. var. obtusifolia Desv. - 1 locality stated by the authors: 41 (leg. SL, 2013).

Rosa jundzillii Bessrer (=R. livescens Bess.) $\mathrm{CE}(\mathrm{s})$. Generally reported from the Park area (Lyubinska et al. 1999, Novosad et al. 2009) and as frequent in the range of 'Podilskyi Tovtry' (Moroz 1970). 2 localities: 26, Vyhvatnivtsi (Khrzhanovsky 1954). Not found during this research.

Rosa porrectidens Chrshan. et Laseb. [R. canina L. $\times R$. jundzillii Bessrer] $-\mathrm{CE}(\mathrm{s})$. Generally reported from the Park area (Lyubinska et al. 1999; Novosad et al. 2009). Not found during this research.

- R. $\times$ subcanina (H. Christ) R. Keller [R. canina L. $\times R$. dumalis Bechst.] - sa-CE-M. The hybrid form not previously reported from the study area. 11 localities stated by the authors: $3,5,8,13,14,18,31,35,36,37$, 41 (leg. SL, 2013).

R. $\times$ subcollina $(\mathrm{H}$. Christ) R. Keller [R. canina L. $\times R$. dumalis Bechst. var. coriifolia (Fr.) Boulenger] - sa-CE-M. 10 localities stated by the authors: 3, 4, 5, 12, 13, 18, 31, 36, 37, 39 (leg. SL, 2013).

\section{Sect. Rosa}

Rosa gallica L. (=R. crenatula Chrshan., $R$. czackiana Besser, Rosa parviuscula Chrshan. \& Laseb) - CE(s)-M(n). The species generally reported from the Park area (Lyubinska et al. 1999; Novosad et al. 2009). 3 localities: 44 (obs. HO, 2009), 24 (Khrzhanovsky 1954), 26 (Khrzhanovsky 1954; Levanets et al. 2004).

\section{Hybrid forms:}

Rosa canina L. $\times$ R. rubiginosa L. - Hybrid of two species of the section Caninae DC. emend. H. Christ. 1 locality stated by the authors: 2 (leg. SL, 2009).

Rosa gallica L. $\times$ R. rubiginosa L. - Hybrid of two species from two separate sections - Rosa and Caninae DC. emend. H. Christ. 1 locality stated by the authors: 30 (leg. SL, 2010).

\section{Species of not clear taxonomical position}

Rosa caryophyllacea Besser - generally reported from the Park area (Lyubinska et al. 1999; Novosad et al. 2009). This species requires taxonomical revision. 


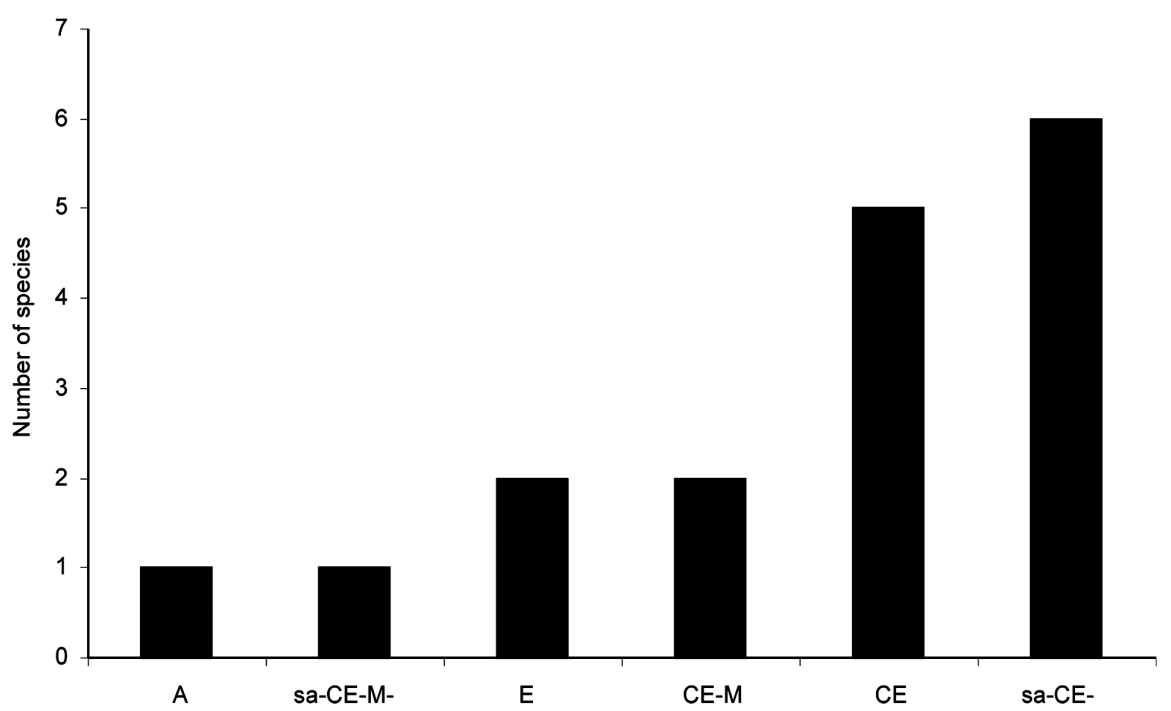

Fig. 3. Geographical elements and sub-elements of roses occurring in the National Nature Park 'Podilskyi Tovtry' (according to: Popek 2007; Zając \& Zając 2001)

Explanations: Asia - Asiatic element, CE - European-temperate sub-element, CE-M - European-temperate-Mediterranean element, sa-CE-M - Europeantemperate-Mediterranean element, sa-CE-M-IR - European-temperate-Mediterranean-Irano-Turanian element, ES - Euro-Siberian sub-element, sa - extension in the beginning of diagnosis to the Atlantic region of Europe

It is distinguished as a separate species (for example: Kurtto et al. 2004, http://www.theplantlist.org, http:// www.gbif.org/species) or as a synonym of $R$. dumalis Bechst (Zieliński 1985; Popek 1996) or R. canina s. 1. (Mirek et al. 2002).

\section{Discussion}

The genus Rosa L. in the 'Podilskyi Tovtry' National Nature Park comprises over $60 \%$ of rose species that were reported from the territory of Europe (Popek 2007). However, the taxonomical status of $R$. caryophyllacea Besser is not clear, so further studies should be taken to solve nomenclatural problems. Three new species for the flora of the National Nature Park were found during this study: $R$. micrantha, Rosa $\times$ subcanina and $R . \times$ subcollina. Among them, $R . \times$ subcanina and $R$. $\times$ subcollina are thought to be of hybrid origin $(R$. dumalis $\times R$. canina) and currently are treated as separate species (Henker 2000).

$R$. spinosissima, R. inodora and R. micrantha, found in single localities, are the rarest among the roses occurring in the studied area. The most frequently appearing species were: $R$. canina (40 localities) and $R$. rubiginosa (30 localities). The largest intraspecific diversity was found in $R$. canina (7 varieties) and $R$. dumalis (4 varieties).

Considering geographical elements and geographical distribution, the abundance of individual rose species is differentiated in the flora of the explored area. The rose species belonging to the European-temperate sub-element and European-temperate-Mediterranean element dominate in NNPPT (Fig. 3). Hybrid R. gallica L. $\times$ R. rubiginosa L. (Fig. 4) seems to be one of more interesting taxa in the studied area. It is a hybrid of the species from two different sections - Rosa and Caninae. There are known hybrid forms between $R$. rubiginosa L. and R. agrestis, as well as $R$. sherardii and R. dumalis within the Caninae section (Zieliński 1987), but a hybrid between $R$. rubigonosa and a species from another sections (like $R$. gallica from the section Rosa, as in this case) was not documented yet. However, there are known hybrids of $R$. gallica with the species from the sections Caninae and Synstylae DC. (Kerényi-Nagy 2012)

Among the recorded species $-R$. micrantha and $R$. inodora are very rare in Ukraine. In Ukraine, the species distribution is limited only to South-West and South-East of Ukraine, so in Ukraine, it occurs within the northern range of its occurrence. $R$. inodora is a species endemic to Europe. $R$. inodora localities were found only in numerous dispersed localities in western part of Ukraine. $R$. micrantha is also a very rare species in Europe (Zieliński 1985; Popek 2007; Kurtto et al. 2004).

R. rubiginosa var. jenensis - characterized by glandless sepals and pedicels (Popek 1996), is a very rare species in South and Middle Europe (Klášterský 1932, 1968) and, thus, draws more attention. Also, two types of R. canina: (glandular pedicels) - R. c. var. andegavensis (leaves glandless on the underside) and $R$. $c$. var. blondeana (leaves glandular on the underside) (Fig. 5) 


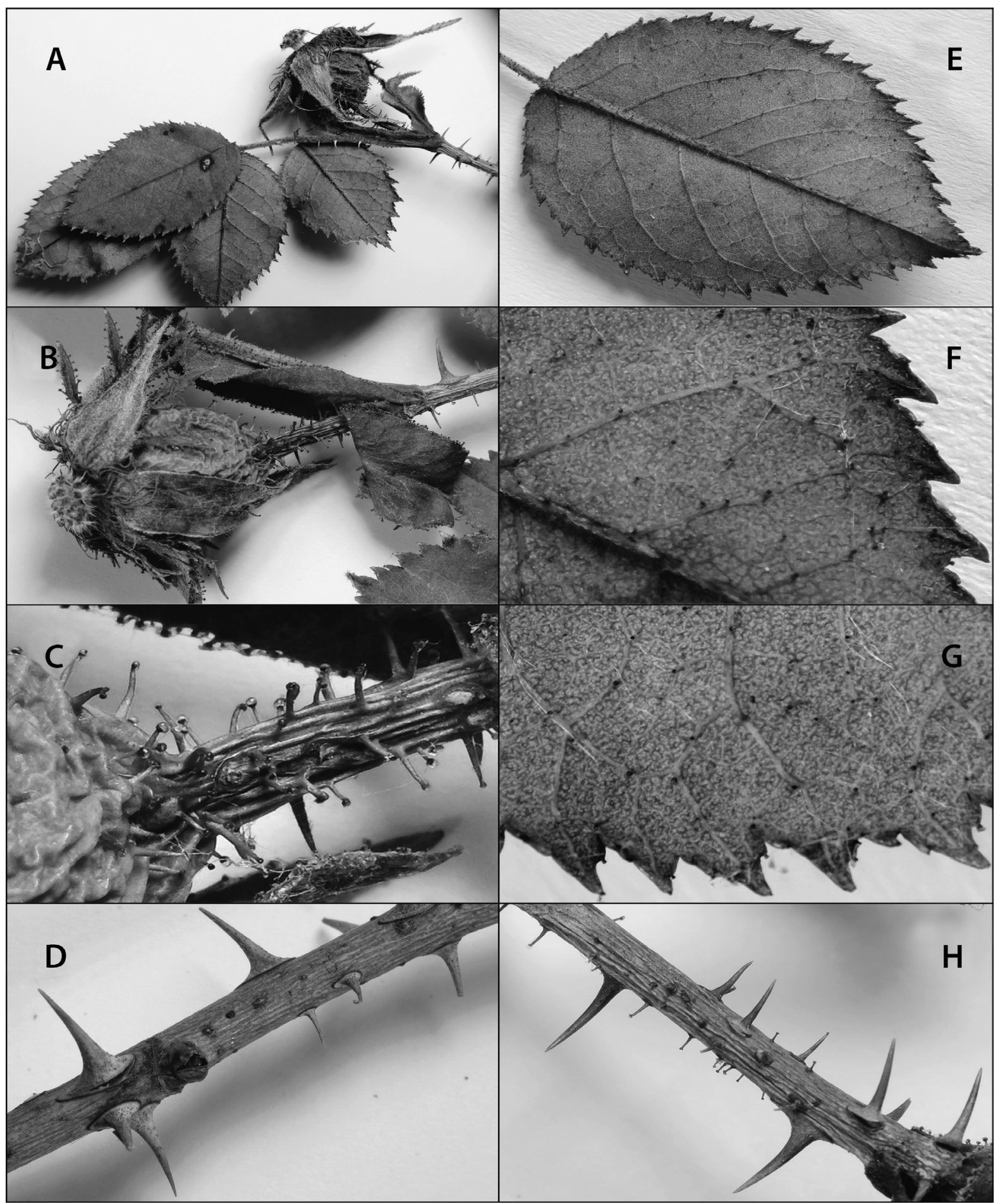

Fig. 4. Examples of morphological characteristics of the intercross hybrid Rosa gallica L. $\times$ R. rubiginosa L.

Explanations: A - top of short shoot, B - hypanthium, C - pedicel, D - part of long shoot, E - leaf (underside), F - part of leaf (underside), G - leaf margin, $\mathrm{H}$ - part of short shoot

are very interesting taxa. Their distribution has not been sufficiently investigated yet and requires further studies. $R$. canina var. deseglise $i$ is often treated synonymously in Ukraine as R. schmalhauseniana Chrshan. It also belongs to rare taxa in Europe (Klášterský 1968). Hairy glandless leaves and glandular pedicels (Popek 1996) are characteristic features of this variety (Popek 1996).
$R$. gallica, recognized in Ukraine as $R$. czackiana Besser, was found in the off road locality in Bakota, and included in 'Red Book of Ukraine' in 2009. The threats to the species include the collecting of specimens due to their esthetic values and the secondary succession of non-forest ecosystems and thermophilous bushes to the species primary localities (Didukh 2009). 


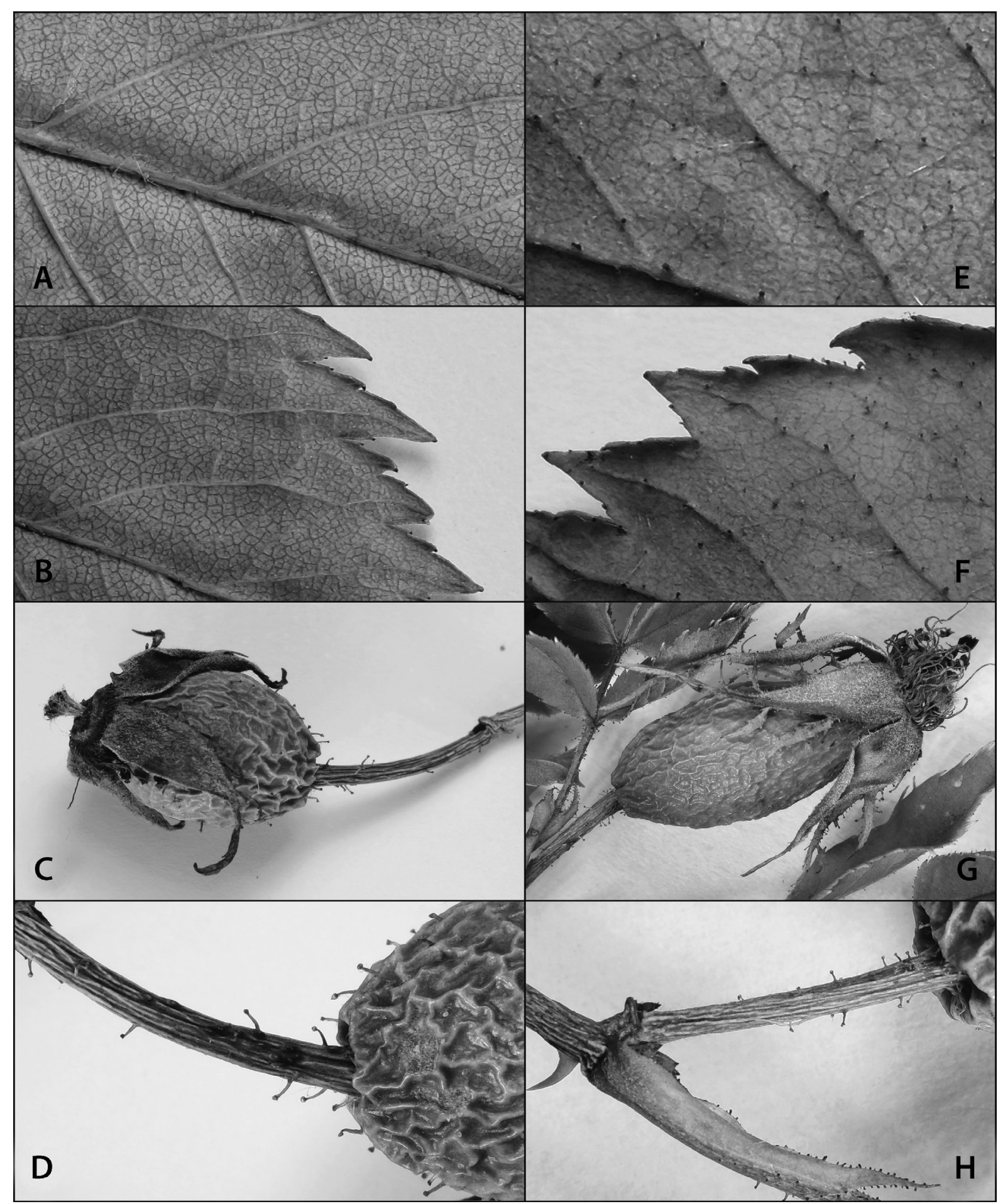

Fig. 5. Examples of morphological characteristics of the Rosa canina L. varieties

Explanations: R.c. var. andegavensis (Bastard) Desp. A - part of leaf (underside), B - leaf margin, C - hypanthium, D - pedicel; R. c. var. blondeana (Ripart) Crépin $\mathrm{E}$ - part of leaf (underside), $\mathrm{F}$ - leaf margin, $\mathrm{G}$ - hypanthium, $\mathrm{H}$ - pedicel

Numerous species mentioned in the literature were not found in the studied area. Their localities in NNPPT territory are presented and their current occurrence in the park cannot be excluded.

The results obtained during the field studies complement the information about the distribution of roses in this part of Ukraine and provide the missing data on the general rose species distribution in Europe. The list of species of roses seems complete. The studies taken so far do not exclude the occurrence of other localities of rare species, therefore, the further exploration of the area, focused on finding most rare species, such as: $R$. gorenkensis or $R$. jundzillii, is needed. 
Acknowledgement. Special thanks to Professor Jerzy Zieliński from the Institute of Dendrology of the Polish Academy of Sciences in Kórnik near Poznań (Poland) for taxonomic consultation and revision of herbarium materials.

\section{References}

Didukh YA. P. (ed.). 2009. Red data book of Ukraine. Vegetable kingdom. 912 pp. Globalcolsating, Kiev.

Henker H. 2000. Rosa. In: H. E. Weber (ed.). Gustav Hegi. Illustrierte Flora von Mitteleuropa. Band 4/2c, pp. 1-108. Parey Buchverlag, Berlin.

http://ww2.bgbm.org/EuroPlusMed/PTaxonDetail.asp?Nam eId $=7716097 \&$ PTRefFk $=7300000$

http://www.eu-nomen.eu/portal/taxon.php?GUID=9596F60F -EC33-4A31-A3FE-0AFEDE057DEE

http://www.gbif.org/species

www.google.pl/maps

http://www.theplantlist.org

http://www.tovtry.com

http://www.tovtry.com/en/info/geo/index.html

http://www.ville-ge.ch/musinfo/bd/cjb/africa/details. php?langue $=$ an $\& i d=200521$

KERÉNYI-NAGY V. 2012. A Történelmi Magyarország területén élő őshonos, idegenhonos és kultúr-reliktum rózsák kismonográfiája. 434 pp, NYME Egyetemi Kiadó, Sopron.

Khrzhanovsky V.G. 1954. Rosa L. In: D. K. Zerov (ed.). Flora URSR, 61, pp. 177-281. National Academy of Sciences of Ukraine, Kiev.

KLÁŠTERSKÝ I. 1932. Rosa jundzillii Besser var. decora Kern. et $R$. agrestis Savi var. gizellae (Borb.) Schlimp. en Bohĕme. Preslia 11: 1-6.

KLÁŠTerský I. 1968. Rosa L. In: T. G. Tutin, V. H. Heywood, N. A. Burges, D. M. Moore, D. H. Valentine, S. M. Walters \& D. A. WebB (eds.). Flora Europea 2, pp. 25-32. Cambridge.

Kurtto A., Lampinen R. \& JunikKa L. 2004. Atlas Florae Europeae 13, pp. 320. Helsinki.

Levanets A. A., Shevera M. V. \& Manturova J. V. 2004. Biodiversity of Kamianets Podilskyi. Preliminary critical inventarisation checklist of plants, fungy and animals, pp. 82-135. Liga-Pres, L’viv.

LyUBinSKa L. H. 2013. Biotopes of National Nature Park 'Podilskyi Tovtry'. Chornomorsk. bot. 9 (3): 459-467.

Lyubinska L. H., Koval'chuk S. I. \& Matveiev M. D. 1999. Pryrodni Tsinnosti Natsional'noho Pryrodnoho Parku 'Podilskyi Tovtry'. Zatverdzheno haukovo- tekhnichnoiu radoiu Natsional'noho Pryrodnoho Parku 'Podilskyi Tovtry'. 51 pp. Kamianets Podilskyi.

Mirek Z., Piękoś-Mirkowa H., Zając A. \& Zając M. 2002. Flowering plants and pteridophytes of Poland. A checklist. In: Z. MireK (ed.). Biodiversity of Poland, 1, 442 pp. W. Szafer Institute of Botany, Polish Academy of Sciences, Kraków.

Moroz Y. Y. 1970. Flora toltrovho kriazha Podolyy y yspol'zovanye ee $\mathrm{v}$ narodnom khoziaistve y dlia yntroduktsyy. Dyss. na stysk. uch. stepeny k. b. n. Kyev.

Mosyakin S. L. \& Fedoronchuk M. M. 1999. Vascular Plants of Ukraine. A Nomenclatural Checklist, pp. 293-296. National Academy of Sciences of Ukraine, M. G. Kholodny Institute of Botany, Kiev.

Novosad V. V., Kryts'ka L. I. \& Lyubins'Ka L. H. 2009. Fitobiota Natsional'noho Pryridnoho Parku 'Podilskyi Tovtry'. Sudynni roslyny, fito- ta flororiznomanittia anotovanyi konspekt spontannoï flory. T. II. 292 pp. Kyiv.

Popek R. 1996. Biosystematyczne studia nad rodzajem Rosa L. w Polsce i krajach ościennych. Prace monograficzne 218, 199 pp. Wyd. Nauk. WSP Kraków.

Popek R. 2007. Dziko rosnące róże Europy. 119 pp. Officina Botanica, Kraków.

SoŁtys-LeleK A. 2013. New species of the genus Rosa L. in the flora of the Podil's'ki Tovtry National Nature Park (Podolian Hills, Western Ukraine). Podil's'ki Čitannâ. Biologiâ. Botanika. Ternopil': 127-132.

ZAJĄC M. \& ZAJĄC A. 2009. The geographical elements of native flora of Poland. $94 \mathrm{pp}$. Edited by Laboratory of Computer Chorology, Institute of Botany, Jagiellonian University, Kraków.

ZIELIŃSKi J. 1985. Studia nad rodzajem Rosa L. - systematyka sekcji Caninae DC. em Christ. Arbor. Kórnickie 30: 3-109.

Zieliński J. 1987. Rosa L. In: A. JAsiewicz (ed.). Flora of Poland, vol 5, 48 pp. Institute of Botany. Polish Academy of Sciences, Cracow. 
Appendix 1. List of localities with geographical coordinates

\begin{tabular}{|c|c|c|}
\hline No & Locality & Geographical coordinates \\
\hline 1 & Sataniv - part E & N49 $15^{\prime} 33^{\prime \prime}$ E26 $15^{\prime} 24^{\prime \prime}$ \\
\hline 2 & SE of Sataniv & N4913'58" E261''' \\
\hline 3 & Zakupne - quarry & N496'46" E26²1'34" \\
\hline 4 & Zakupne & N496'17" E26²1'11" \\
\hline 5 & Zakupne - quarry 1 & N496'14" E26¹9'44" \\
\hline 6 & S of Zakupne & N495'41" E26¹9'53" \\
\hline 7 & E of Vilhivtsi & N494'47" E26¹7'32" \\
\hline 8 & Demkivtsi & N494'14" E26²3'44" \\
\hline 9 & $\mathrm{~N}$ of Smotrych & N48 59'46" E26 $33^{\prime} 13^{\prime \prime}$ \\
\hline 10 & S of Smotrych & N48 51'44" E26 36'14" \\
\hline 11 & Nihyn - part N & N48 5'47" E26 33'42" \\
\hline 12 & Nihyn - tovtry & $\mathrm{N} 48^{\circ} 5^{\circ} 2^{\circ}$ " E26 $33^{\prime} 4^{\prime \prime}$ \\
\hline 13 & Verbka - part N & N48 49'9" E26³7'26" \\
\hline 14 & Verbeckie Tovtry & N4848'28" E26 $36^{\prime} 5^{\prime \prime}$ \\
\hline 15 & Verbka - near quarry, rocks & N48 47'54" E26 $37^{\circ} 28^{\prime \prime}$ \\
\hline 16 & Pryvorottia II & N484'36" E26 $38^{\prime} 57^{\prime \prime}$ \\
\hline 17 & To W from Orynyn & $\mathrm{N} 48^{\circ} 45^{\prime} 55^{\prime \prime} \mathrm{E} 26^{\circ} 2^{\circ 10 "}$ \\
\hline 18 & Orynyn & N48 $45^{\prime} 49^{\prime \prime} \mathrm{E} 26^{\circ} 22^{\prime} 7^{\prime \prime}$ \\
\hline 19 & E of Pryvorottia & N48 44'43" E26 21'6" \\
\hline 20 & Adamivka & N484'ㄷ' E26 $18^{\prime} 38^{\prime \prime}$ \\
\hline 21 & Chornokozyntsi & N483'ㄷ' E26 $16^{\prime} 55^{\prime \prime}$ \\
\hline 22 & W of Kizya Kudrynetska & N48 $37^{\prime} 22^{\prime \prime}$ E26 $19^{\prime} 2^{\circ \prime \prime}$ \\
\hline 23 & W of Liskivtsi & N484'18" E262'ㄴ' \\
\hline 24 & Surzha & N48 $39^{\prime} 41^{\prime \prime}$ E26 $29^{\prime} 25^{\prime \prime}$ \\
\hline 25 & Pudlivtsi - quarry & N4843'23" E263''" \\
\hline 26 & Kamianets Podilskyi & N48 $4^{\circ} 11^{\prime \prime} \mathrm{E} 26^{\circ} 33^{\prime} 52^{\prime \prime}$ \\
\hline 27 & Zhovtneve & N48 $39^{\prime} 25^{\prime \prime}$ E26 $37^{\prime} 4^{\circ} "$ \\
\hline 28 & Slobidka-Kulchiievetska & N4839'21" E26 $39^{\prime} 58^{\prime \prime}$ \\
\hline 29 & Surzhynieckyi Ravine & $\mathrm{N} 48^{\circ} 4^{\circ} 55^{\prime \prime} \mathrm{E} 26^{\circ} 47^{\prime} 25^{\prime \prime}$ \\
\hline 30 & Mukshanskyi Reserve & $\mathrm{N} 48^{\circ} 38^{\prime} 1^{\circ} \mathrm{E} 26^{\circ} 38^{\prime} 4^{\circ \prime \prime}$ \\
\hline 31 & $\mathrm{~N}$ of Ustia & N48 34'44" E26 $38^{\prime} 37^{\prime \prime}$ \\
\hline 32 & NE of Ustia & N483'ㄹ'" E26 $39 ' 21^{\circ}$ \\
\hline 33 & SE of Ustia & N4832'31" E264'ㄱ' \\
\hline 34 & Bay of Muksha river & N48 $34^{\prime} 44^{\prime \prime}$ E26 $42^{\prime} 16^{\prime \prime}$ \\
\hline 35 & Tarasivka & N48 $36^{\prime} 23^{\prime \prime} \mathrm{E} 26^{\circ} 4^{\circ} 48^{\prime \prime}$ \\
\hline 36 & W of Vrublivtsi & N4837'3" E2643'53" \\
\hline 37 & S of Vrublivtsi & N48 $34^{\prime} 48^{\prime \prime}$ E26 $45^{\prime} 5^{\circ \prime \prime}$ \\
\hline 38 & Vrublivtsi & N48 $36^{\prime} 27^{\prime \prime}$ E26 $45^{\prime} 43^{\prime \prime}$ \\
\hline 39 & Kytaihorod & $\mathrm{N} 48^{\circ} 38^{\prime} 2^{\circ \prime \prime} \mathrm{E} 26^{\circ} 47^{\prime} 2^{\circ \prime \prime}$ \\
\hline 40 & Demshyn & N4837'6" E2649'54" \\
\hline 41 & Subich & N48 $35^{\prime} 41^{\prime \prime}$ E26 $49^{\prime} 47^{\prime \prime}$ \\
\hline 42 & Kolodiivka - by the Dniester river & N48 $35^{\prime} 37^{\prime \prime}$ E26 $56^{\prime} 56^{\prime \prime}$ \\
\hline 43 & SE of Kolodiivka & N48 $35^{\prime} 44^{\prime \prime}$ E26 $56^{\prime} 3^{\circ \prime \prime}$ \\
\hline 44 & Bakota & N4835'7" E27 \\
\hline
\end{tabular}

